\title{
PARAPATICS ANDREA: A magyar nyelv regionalitása és a köznevelés.
}

Tények, problémák, javaslatok. Budapest, Tinta Könyvkiadó, 2020. (136 lap)

A Tinta Könyvkiadó az elmúlt években több olyan kiadványt jelentetett meg, melyek a nyelvjárások témakörét érintik, $\mathrm{s}$ a felsőoktatásban és közoktatásban is jól hasznosíthatók. Ezt a sort folytatja az a 2020-ban napvilágot látott munka, mely Parapatics Andrea nyelvjárásokkal, illetve az anyanyelvi neveléssel kapcsolatos kutatásainak jól szerkesztett, átfogó gyüjteménye.

Nem véletlen az a nagyfokú figyelem, ami a nyelvjárásokra mint a laikusok szerint „kihalóban lévő” nyelvváltozatra irányul. Számos empirikus kutatás igazolta, hogy mind Magyarországon, mind a határon túli területeken nagy arányban elsődlegesen valamely helyi nyelvváltozatot sajátítanak el s használnak ma is a magyar anyanyelvü beszélők. A kérdéssel foglalkozó nyelvészek körében ezek a körülmények vitathatatlanok. Ennek megfelelően számos olyan tanulmány született az elmúlt évtizedekben, mely sürgető feladatként határozta meg az anyanyelvoktatás módszereinek megújítását, $\mathrm{s}$ az anyanyelvváltozatot figyelembe vevő hozzáadó szemlélet hatékonyságát kívánta igazolni. Bár történtek pozitív irányú változások az anyanyelv oktatását szabályozó dokumentumokban, a többnormájú szemlélet egyelöre csak elméletben van jelen a magyar tannyelvü oktatási intézmények legtöbbjében. Amíg ez így van, negatív megkülönböztetésben részesül(het) nagyon sok magyar anyanyelvi beszélő anélkül, hogy bármilyen alapja lenne a diszkriminációnak. Mindezek okaként a hiányos, kevéssé tudatos metanyelvi ismereteket említik a kérdés kutatói.

Parapatics Andrea a tudományosan megalapozott metanyelvi ismereteknek a terjesztését végzi hosszú évek óta nyelvészként, egyetemi oktatóként, gimnáziumi magyartanárként. Az elmúlt tíz évben hazai és nemzetközi folyóiratokban magyarul és idegen nyelven megjelent kutatási eredményeinek, tanulmányútjainak tapasztalatait, továbbá gyakorló pedagógusként eredményesen alkalmazott feladatgyüjteményeit szerkesztette egésszé az itt ismertetett kötetben. A munka szemléletén érződik az elhivatottság, a személyes érintettség és az alapos szakmai tájékozottság, felkészültség. Az alcím előrevetíti a szerző sikeresen megvalósított célkitüzését: 1 . a legfrissebb magyar és nemzetközi szakirodalom alapján vázolt elméleti keretben ismerteti meg az olvasókat a regionalizmusokkal, a megítélésükkel kapcsolatos tényekkel, 2. változatos módszerekkel gyüjtött és elemzett adatokon keresztül szemlélteti a megoldásra váró problémákat, 3. külföldi példákat elénk állítva, gazdag módszertani anyagot mellékelve javaslatokat tesz ezeknek a megoldására is. Eközben a bemutatott helyzetért nem tesz felelössé senkit, különösen nem a pedagógusokat. Ezt már az előszóban s a szövegben is többször olvashatjuk. A közös problémákra közös megoldást keres és mutat a kötet. 
A szerzői előszót öt nagyobb fejezet, kétnyelvü összegzés s gazdag szakirodalmi jegyzék követi.

Az első fejezet felvázolja azokat a társadalmi változásokat, amelyek hatására kétségtelenül módosult a nyelvjárások használati köre: a köznyelv nagy mértékben hatott a nyelvjárásokra, ugyanakkor a területi változatok bizonyos elemei beszivárogtak a köznyelvbe. A globalizációs folyamatok mellett egyre inkább felerősödik a helyi, regionális kötődések jelentősége. Az egyre szélesebb körben terjedő glokális jelző (a globális és a lokális szavak kontaminációja) a nyelvváltozatok esetében a regionális köznyelviség funkcióját is kifejezheti. Hiszen ez a változat a nyelvjárási hátterü beszélők számára a standard szerepét töltheti be, ugyanakkor jelzi a szükebb helyi és közösségi identitást is. Ezek pedig korántsem a kihalás szélén álló változatok, hanem a kettősnyelvüvé vált emberek mindennapos kommunikációjának eszközei. Bár ennek legtöbbször az adott beszélők sincsenek tudatában, nem kívánnak azonosulni az alacsony presztízsű regionális nyelvváltozattal.

A második fejezet elején azt vázolja a szerző, hogy ennek az általános megbélyegző attitüdnek - mely sok esetben lingvicizmushoz vezethet — az okai között fellelhető a következetlen, sokszor ellentmondásos információáradat, mely a regionális változatokkal kapcsolatban akár a köznevelésen, akár a nyilvánosságon keresztül hat a beszélőkre. Ez különösen érvényes a centralizáltabb, (volt) diktatórikusabb társadalmakra, ahol a nyelvek, nyelvváltozatok közötti hierarchia érvényesül, s egyetlen „helyes” nyelvi megoldásként a standardot fogadják el. Ennek alátámasztásaként két kutatás eredményeit ismerhetjük meg a fejezetben.

Az első, online kérdőívvel végzett felmérés 548 nappali tagozatos egyetemistát kérdezett „hólabdamódszerrel” a nem köznyelvi változatokról. A vizsgált csoporttól érkezett válaszok hiteles képet rajzolnak a korábbi évek közoktatásának a nyelvjárásokhoz, a nyelvjárási beszélőkhöz füződő attitüdjéről, s előrevetítik (többek között) a társadalom leendő pedagógusainak metanyelvi tájékozottságát. Bár korrelációs elemzésekre nem kerül sor a fejezetben, az összesített adatok így is tanulságosak. A fiatalok nagy arányban (az adatközlők közel fele) számoltak be arról, hogy javították már ki őket regionális színezetü beszédük miatt, 43,4\%-uk pedig egy ötfokú skálán az egyest (legkevésbé), 28,5\%-uk a kettest jelölte meg arra a kérdésre válaszolva, hogy milyen mértékben beszél tájszólásban. A kutatás során megkérdezett adatközlök „elméleti síkon többnormájúságot és toleranciát hirdetnek, a gyakorlatban viszont ezek az adatközlök is kijavítottak, illetve kinevettek már pusztán helytelennek gondolt, egyébként regionális nyelvi jelenségeket" (21).

Az idősebb korosztály vélekedését a nyelvváltozatokról az Új magyar nyelvjárási atlasz szociolingvisztikai kérdőívével gyüjtött adatok alapján elemzi a szerző: 8 kutatópontról 51 adatközlővel készült beszélgetés anyaga alapján igazolja 
vagy éppen cáfolja hipotéziseit. A vizsgált személyek pozitívan nyilatkoztak saját lakóhelyük nyelvhasználatáról, és toleránsak más vidékek regionális jegyeivel szemben is. Csupán öt ember számolt be arról, hogy negatív élménye adódott nyelvjárási beszédéből. Azt is megtudjuk, hogy bár a kapott eredmények nincsenek összefüggésben az adatközlők iskolai végzettségével; az idősebb korosztály metanyelvi ismeretei hiányosabbak ugyan, mégis elfogadóbbak a nyelvi változatossággal szemben. Különösen azok, akik érzékelik, fel-, illetve elismerik saját beszédük regionális jegyeit.

A harmadik fejezet eredményei nagy mértékben hozzájárulhatnak ezeknek a regionális jegyeknek a tudatosításához: olyan empirikus kutatások során, passzív módon vagy éppen résztvevő megfigyeléssel gyüjtött nyelvi adatokat elemez a szerző, melyek bizonyítják, hogy a fiatal korosztály is ismer, sőt használ tájszavakat szóban és írásban egyaránt.

Parapatics Andrea 2014-ben (112 tanuló) és 2018-ban (200 tanuló) tapolcai gimnazisták körében végzett kérdőíves gyüjtést: A magyar nyelvjárások atlaszának 88 tájszaváról kérdezte a fiatalokat. Mindkét vizsgálat adatai alapján kijelenthető, hogy a 14-18 éves fiatalok ismerik, használják a felsorolt szavak egy részét ma is, persze különböző arányban. Ugyanez mondható el a 2019-ben megkérdezett (60 tanuló) siófoki fiatalokról is. Tízéves tapolcai magyartanári gyakorlata során résztvevő megfigyelésre is lehetősége adódott a szerzőnek: ezek alapján állíthatja, hogy a nyelvjárási régió jellemzői a tanulók iskolai szóbeli és írásbeli produkcióiban is megfigyelhetők. Ezeket a tapasztalatokat számos dolgozat, érettségi vizsgadolgozat részletével támasztja alá, $\mathrm{s}$ igazolja, hogy a témakör nemcsak „hagyományként”, „érdekességként” van jelen az oktatásban, hanem a mindennapi nyelvhasználat részeként is.

A mindennapi nyelvhasználat vizsgálatakor nem kerülhető meg a digitális tér nyelvészeti elemzése sem. Parapatics Andrea objektív és szubjektív nyelvi adatokat gyüjtött véletlenszerü mintán, nyilvános bejegyzésekben és privát beszélgetésekben hipotéziseinek igazolására. Azt feltételezte, hogy ezekben a bejegyzésekben számos esetben találkozhatunk nyelvjárási jegyekkel, s ezek valamilyen reakciót is kiváltanak az olvasókból. Azt is feltételezte, hogy ezek a megnyilvánulások az egynormájú nyelvszemléletet tükrözik inkább. Hipotézisei beigazolódtak: az előforduló regionalizmusokra érkező reakciók hiányos ismereteken alapuló, különböző nyelvi mítoszokat terjesztő hozzászólások, melyek széles körben, gyorsan terjed(het)nek a különböző nyilvános, sokszor ismeretlen embereket tömörítő csoportokban. Éppen ezt a lehetőséget lenne fontos kihasználni a tudományos alapú, hiteles információk terjesztésére: akár a nyelvjárásokról. Hiszen ezek nemcsak mások nyelvhasználatával szemben tehetik toleránsabbá a közösséget, hanem saját lokális (nyelvi) identitásukban is megerősíthetik a beszélöket (62). 
A következő fejezet a magyarországi hivatalos köznevelési dokumentumok (a kézirat leadásakor érvényben lévő 2012-es NAT) anyanyelvoktatással kapcsolatos célkitüzéseivel összefüggésben mutat be egy pedagógusok körében végzett empirikus felmérést. Korábbi vizsgálatok is bizonyították, hogy a hivatalos dokumentumokban megfogalmazott többnormájú, toleráns szemlélet gyakorlatban való megvalósulása lassú folyamat, hiszen a pedagógusok valóban magukévá kívánják tenni a hozzáadó szemléletet, valójában viszont nincsenek felkészülve a megfogalmazott célok elérésére. Ebből adódóan sokszor diszkriminatív módon nyilvánulnak meg a nem standard változatot használó tanulókkal szemben, gyakran szándékuk ellenére. Ezt támasztja alá a szerző által 170 pedagógus bevonásával végzett kérdőíves felmérés is. A válaszadók elfogadó attitüdről vallottak, valójában azonban számos tévhit határozta meg válaszaikat. A nyelvjárási beszédet leginkább a falusi, az idősebb, a határon túli, az alacsony iskolai végzettségü személyeknek tulajdonították. Tanítványaik nyelvi megnyilatkozásaiban csupán 21 személy ismerte fel, illetve ismerte el a tájszólást. Arról is vallottak, hogy felsőfokú tanulmányaik során nem hagyott „mély nyomot” bennük a dialektológia óra, és sokszor mellozzik pedagógiai gyakorlatuk során a nyelvjárások témakörét más, fontosabbnak vélt tananyag javára. A kollégák azt is felvetették, hogy hasznos lenne gyakorlati anyagok készítése a témakörhöz.

A kötet ötödik fejezetében ezekből is ízelítőt kaphat az olvasó. Elöször a magyar és a nemzetközi szakirodalom alapján vázolja fel Parapatics Andrea azokat az érveket, követendő mintákat, amelyek a nyelvjárások és a köznyelv egyenrangúságának tényét támasztják alá, és segítik a kiegyensúlyozó-funkcióelkülönítő attitüd terjesztését. Olaszország, Németország, Franciaország, Észtország, Lengyelország, Finnország, Skócia, Észak-Ciprus nyelvi, nyelvjárási helyzetéről színes, tanulságos beszámolókat kapunk. Norvégia gyakorlata tünik legelfogadóbbnak, éppen ezért követendőnek. A norvég kettősnyelvü tanulók bizonyítottan kimagaslóan teljesítenek a különböző tanulmányi felméréseken. Ez azokat a kutatásokat támasztja alá, melyek a kettősnyelvüség kapcsán (a kétnyelvüség előnyeihez hasonlóan) kiemelik annak a kognitív fejlődésre gyakorolt pozitív hatásait. A továbbiakban olyan segédleteket, internetes oldalakat, alkalmazásokat ismerhetünk meg, melyek ennek a kettősnyelvüségnek a kialakítását segíthetik a magyar nyelvterületen. A szerző által közölt feladatok nemcsak a közoktatás szintjén, hanem a felsőoktatásban is haszonnal alkalmazhatók a nyelvi regionalitás tudatosítása, az elfogadó szemlélet terjesztése céljából akár Magyarországon, akár a külső nyelvi régióban. Eredményesen használható az a két elemzés is, mely Nagy László és Szabó Magda irodalmi munkássága alapján vázolja a helyi nyelvváltozat szerepköreit, jelentőségét. Hiszen ezekben az alkotásokban nem csupán stilisztikai eszközként jelennek meg az otthonról hozott nyelvi jelenségek: a helyi kötődést, az összetartozást is jelzik használatukkal a szerzők. 
A munkát két nyelven közölt összegzéssel zárja a szerző, melyben megfogalmazza meggyőződését, miszerint a megfelelően felkészített pedagógusok toleránsan kezelik tanítványaik regionális nyelvi megnyilatkozásait, s ezzel ezt a szemléletet adják tovább a felnövekvő nemzedéknek. Azzal is tisztában van azonban, hogy ez széles körben csak összehangolt, következetes ,többlépcsős nyelvinyelvjárási stratégiával érhető el, amely lépcső valamennyi fokán mindenki teljesíti a tőle elvárt befektetést, legyen szó energiáról, erkölcsi vagy anyagi támogatás biztosításáról” (116).

Parapatics Andrea könyve több mint ezer különböző korú, nemü, iskolai végzettségü adatközlő bevonásával, többféle módszerrel gyüjtött adatokat elemez. Mégis egységes munkát alkot, mivel a gazdag szakirodalmat bemutató elméleti keretbe helyezve mindegyik kutatás olyan problémát jár körül, mely az anyanyelvoktatás hatékonysága, a pozitív nyelvi öntudat, a magabiztos nyelvhasználat szempontjából kiemelt fontosságú. Az elemzések közben megfogalmazott javaslatok, a regionális jegyek tudatosítására felvázolt lehetőségek valóban hozzájárulhatnak ahhoz a célhoz, amit a szerző a következőképpen fogalmaz meg: „legalább a magyartanár képes legyen meggyőzni diákjait a nyelvjárások értékeiről, létjogosultságáról, a megbélyegzés alaptalanságáról és helytelenségéről, hogy valóban azt „gyomlálhassa ki” a felnövekvő nemzedékekből, amit kell: nem a nyelvi sokszínüséget és az ahhoz kötődő lokális identitást, hanem a hiányos müveltségen alapuló elöítéletes gondolkodást" (89).

A nyelvjárásokhoz, a nyelvjárási beszélökhöz kapcsolódó tévhitek eloszlatásához, a metanyelvi ismeretek fejlesztéséhez a kiadvány szerzője nagy mértékben hozzájárult eddig is mind a felsőoktatásban, mind a köznevelésben, mind pedig a tudományos ismeretterjesztés területén kifejtett elhivatott, tudományosan megalapozott, hiteles törekvéseivel. Az itt bemutatott kötet jól áttekinthetően, közérthetően foglalja össze ezeknek a törekvéseknek az eredményeit.

DUDICS LAKATOS KATALIN ORCID: 0000-0003-1354-4421

II. Rákóczi Ferenc Kárpátaljai Magyar Főiskola, Beregszász dudics.katalin@kmf.org.ua 